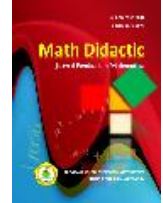

MATH DIDACTIC: JURNAL PENDIDIKAN MATEMATIKA

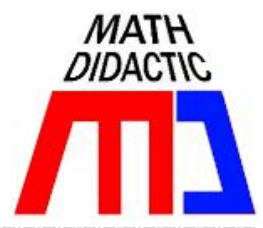

\title{
DESKRIPSI BERPIKIR TINGKAT TINGGI SISWA SMP DALAM MENYELESAIKAN SOAL PISA KONTEN CHANGE AND RELATIONSHIP
}

\section{DESCRIPTION OF JUNIOR HIGH SCHOOL STUDENTS' HIGHER ORDER THINGKING IN SOLVING PISA PROBLEM ON CHANGE AND RELATIONSHIP CONTENT}

\author{
Mochamad Hendri Kusuma, Novisita Ratu \\ Program Studi Pendidikan Matematika FKIP Universitas Kristen Satya Wacana Salatiga \\ 202015069@student.uksw.edu, novisita.ratu@staff.uksw.edu
}

\begin{abstract}
Abstrak: Jenis penelitian ini adalah deskriptif kualitatif yang bertujuan untuk mendeskripsikan kemampuan berpikir tingkat tinggi siswa SMP dalam menyelesaikan soal matematika PISA pada konten change and relationship. Subjek dalam penelitian ini adalah 2 siswa kelas IX SMP Negeri 1 Salatiga tahun pelajaran 2018/2019 yang memiliki kemampuan matematika tinggi. Metode pengumpulan data pada penelitian ini adalah tes, wawancara, dan dokumentasi. Penelitian ini menggunakan teknik reduksi data, penyajian data dan penarikan kesimpulan dalam analisis data. Berdasarkan hasil analisis diperoleh (1) subjek INA dan subjek PSP mampu mencapai semua level berpikir tingkat tinggi mulai dari menganalisis (C4), mengevaluasi (C5), dan mencipta/mengkreasi (C6), (2) kedua subjek menunjukkan adanya perbedaan penyelesaian pada soal C5 dan C6 namun tidak ada perbedaan penyelesaian untuk soal $\mathrm{C} 4$.
\end{abstract}

Kata Kunci: HOT, PISA, Change And Relationship

Abstract: This research is a qualitative descriptive which aims to describe junior high school students' higher order thingking skill to solve PISA mathematical problems on change and relationship content. Subjects in this research were two grade IX students of SMP N 1 Salatiga on academic year 2018/2019 who had high mathematical skill. Data collecting methods are test, interview, and documentation. This research uses data reduction, data display and conclusion drawing in data analyzing. Based on the results of the analysis are gained (1) subject INA and subject PSP can achieve all level of higher order thinking starting from analyzing (C4), evaluating (C5), and creating (C6), (2) the two subject show different solving in the C5 and C6 problems but there's no difference for the $C 4$ problems.

Keywords: HOT, PISA, Change And Relationship

Cara Sitasi: Kusuma, M.H., \& Ratu, N. (2018). Deskripsi berpikir tingkat tinggi siswa SMP dalam menyelesaikan soal PISA konten change and relationship. Math Didactic: Jurnal Pendidikan Matematika, 4(2), 155-168. 
PISA adalah studi internasional tentang prestasi literasi membaca, matematika, dan sains siswa sekolah berusia 15 tahun yang diadakan setiap 3 tahun oleh Organization for Economic Co-operation and Development (OECD). Berdasarkan PISA International Survey, Indonesia selalu berada pada urutan sepuluh terbawah dibandingkan negara-negara lainnya terutama pada literasi matematika. Hasil PISA Indonesia pada literasi matematika dari tahun 2003 sampai 2015 dapat dilihat pada Tabel 1 berikut.

Tabel 1. Hasil PISA Indonesia Pada Literasi

\begin{tabular}{cccc} 
Tahun & $\begin{array}{c}\text { Nilai } \\
\text { Rerata }\end{array}$ & Peringkat & $\begin{array}{c}\text { Jumlah Negara } \\
\text { Peserta }\end{array}$ \\
\hline 2000 & 367 & 39 & 41 \\
2003 & 360 & 38 & 40 \\
2006 & 391 & 50 & 57 \\
2009 & 371 & 61 & 65 \\
2012 & 375 & 64 & 65 \\
2015 & 386 & 62 & 70 \\
\hline
\end{tabular}

Sumber: Susanti \& Syam (2017, hal. 32)

Tabel 1 di atas menunjukkan bahwa hasil capaian literasi matematika Indonesia masih di bawah rerata negara-negara lain yang turut berpartisipasi dalam studi PISA. Artinya, hasil capaian Indonesia pada tiap komponen literasi matematika yang diujikan dalam PISA masih rendah dan tertinggal dari negara lain. Tiga komponen utama dalam literasi matematika yang di identifikasi pada studi PISA adalah konten, proses, dan konteks. Komponen konten dimaknai sebagai isi atau materi atau subjek matematika yang dipelajari di sekolah (Wardhani dan Rumiyati, 2011, hal. 15-16). Terdapat 4 kategori materi yang diujikan kepada siswa dalam komponen konten untuk literasi matematika. Salah satunya adalah perubahan dan keterkaitan (change and relationship).

Change and relationship merupakan kategori materi yang secara matematis berkaitan dengan pemodelan suatu perubahan dan hubungan yang sesuai dengan fungsi dan persamaan, serta menciptakan, menginterpretasi, dan menerjemahkan suatu hubungan antara simbol dan grafik. Dalam kurikulum Indonesia, kategori ini berkaitan dengan materi fungsi dan aljabar dimana bentuk aljabar, persamaan, pertidaksamaan, representasi dalam bentuk tabel dan grafik merupakan sentral dalam menggambarkan, memodelkan, dan menginterpretasi perubahan dari suatu fenomena (OECD, 2015, hal. 6).

Pada hasil PISA tahun 2012, Indonesia hanya memperoleh nilai rata-rata sebesar 364 dan menempati posisi 3 negara terendah untuk konten change and relationship bahkan sangat jauh tertinggal dari negara tetangga Singapura dan Vietnam yang memperoleh nilai rerata berturut-turut 580 dan 509 pada konten tersebut (OECD, 2012, hal. 13). Kondisi ini mengindikasikan bahwa kemampuan siswa Indonesia usia 15 tahun dalam menggambarkan, memodelkan, dan menginterpretasi perubahan dari suatu fenomena masih rendah.

Pendapat tersebut diperkuat oleh Edo, dkk (2012, hal. 55) yang menyatakan bahwa selama ini siswa Indonesia tidak terbiasa dengan soal yang berbau pemodelan, dimana kemampuan untuk menerjemahkan masalah sehari-hari ke dalam bentuk matematika formal dibutuhkan sehingga hasil pada literasi matematika tersebut rendah. Dengan kata lain, berpikir tingkat tinggi (Higher Order Thinking/HOT) siswa Indonesia usia 15 tahun masih rendah karena umumnya soal PISA didesain untuk mengukur HOT siswa. Hal itu didukung oleh hasil penelitian Setiawan, dkk (2014, hal. 250) yang menyatakan bahwa melalui soal matematika PISA siswa diuji HOT nya.

HOT adalah proses berpikir yang mengharuskan siswa untuk memanipulasi 
informasi dan ide-ide dengan cara tertentu yang memberikan mereka pengertian dan implikasi baru (Gunawan, 2003, hal. 171). Sedangkan Heong, dkk (2011, hal 121) menyatakan bahwa HOT adalah berpikir pada tingkat yang lebih tinggi dari pada sekedar menghafal fakta atau mengatakan suatu informasi kepada seseorang. Berdasarkan Taksonomi Bloom Revisi, HOT termasuk dalam dimensi proses berpikir sebagaimana yang terdapat dalam dimensi proses berpikir Taksonomi Bloom yang telah disempurnakan oleh Anderson \& Krathwohl pada tahun 2001 yang terdiri atas kemampuan mengingat/mengetahui (knowing-C1), memahami (understanding-C2), menerapkan/mengaplikasikan (aplying-C3), menganalisis (analyzing-C4), mengevaluasi (evaluating-C5), dan mengkreasi (creatingC6) (Widana, 2017, hal. 3). Menurut Utari, HOT berada pada 3 level teratas yaitu analyzing-C4, evaluating-C5, dan creating-C6 (Syahwaludi, dkk, 2016, hal. 3).

Terdapat beberapa penelitian tentang HOT yang sudah pernah dilakukan, salah satu penelitian tentang tingkat kemampuan berpikir siswa pernah dilakukan oleh Mujaid (2015, hal. 97-99) pada siswa kelas XI SMA Negeri 1 Balai Riam yang diperoleh kesimpulan bahwa: (1) tingkat pemikiran matematika siswa kelas XI IPA dan XI IPS SMA Negeri 1 Balai Riam masih pada tingkatan rendah (low-order mathematical thinking), (2) kemampuan berpikir matematika siswa pada tingkatan $\mathrm{C} 4$ (menganalisis) dan C5 (mengevaluasi) siswa IPA dan IPS belum maksimal, (3) tingkat pemikiran matematika siswa IPA dan IPS belum sampai pada tingkatan C6 (mencipta). Penelitian dengan topik serupa juga pernah dilakukan oleh Syahwaludi dkk (2016, hal. 1011) pada siswa kelas XI IPA MAN 2 Pontianak yang diperoleh kesimpulan bahwa: (1) siswa kategori tinggi mampu menyelesaikan masalah statistika dengan cara menganalisis, mengevaluasi, dan masih dianggap kurang dalam mencipta ide atau cara pandang yang baru untuk menyelesaikan masalah, (2) siswa kategori sedang mampu menyelesaikan masalah statistika dengan cara menganalisis, masih dianggap kurang dalam mengevaluasi, dan belum mampu dalam mencipta ide atau cara pandang yang baru untuk menyelesaikan masalah, (3) siswa kategori rendah mengalami kesulitan dalam menganalisis suatu masalah, mengevaluasi, dan belum mampu dalam mencipta ide atau cara pandang yang baru untuk menyelesaikan masalah, (4) siswa kategori sangat rendah mengalami kesulitan dalam menganalisis suatu masalah, belum mampu mengevaluasi suatu masalah, dan belum mampu dalam mencipta ide atau cara pandang yang baru untuk menyelesaikan masalah.

Mengacu pada hasil capaian matematika negara Indonesia pada PISA yang masih rendah dan tertinggal dari negara-negara lain yang ikut berpartisipasi dalam studi PISA terutama pada konten change and relationship serta keragaman hasil penelitian tentang kemampuan berpikir matematika siswa yang sudah pernah dilakukan, peneliti tertarik untuk mengidentifikasi bagaimana HOT siswa usia 15 tahun berdasarkan Taksonomi Bloom Revisi dalam menyelesaikan soal PISA konten change and relationship.

Berdasarkan latar belakang tersebut, maka dapat dirumuskan masalah dalam penelitian ini yaitu "Bagaimana kemampuan berpikir tingkat tinggi siswa SMP yang berusia 15 tahun dalam menyelesaikan soal PISA konten change and relationship?" Penelitian ini diharapkan mampu memberikan gambaran kepada guru terutama dalam pembelajaran matematika mengenai level berpikir tingkat 
tinggi yang dimiliki oleh siswa sehingga guru mampu menerapkan strategi pembelajaran yang sesuai dengan kemampuan berpikir siswa.

\section{Metode Penelitian}

Jenis penelitian yang digunakan adalah penelitian deskriptif kualitatif. Subjek penelitian ini merupakan 2 siswa kelas IX SMP Negeri 1 Salatiga pada semester ganjil tahun ajaran 2018/2019. Pengambilan sampel menggunakan teknik purposive sampling, yaitu siswa dipilih untuk dijadikan subjek penelitian berdasarkan beberapa pertimbangan. Adapun pertimbangan tersebut antara lain: (1) berusia 15 tahun, (2) berkemampuan matematika tinggi berdasarkan hasil tes berpikir tingkat tinggi dalam menyelesaikan soal PISA, (3) kesanggupan subjek untuk mengerjakan soal tes dan wawancara, dan (4) merupakan hasil diskusi dan rekomendasi dari guru matematika yang mengampu subjek tersebut terutama untuk siswa yang mudah berkomunikasi.

Penelitian ini menggunakan teknik pengumpulan data dengan metode dokumentasi, tes dan wawancara. Hasil tes atau data dalam penelitian ini akan menjadi bahan yang akan dianalisis mengenai kemampuan berpikir tingkat tinggi dalam menyelesaikan soal PISA. Wawancara dilakukan secara mendalam (in depth interview), lebih bebas, dan bersifat semi terstruktur sehingga peneliti dapat mengembangkan sendiri pertanyaan yang akan diajukan untuk memperoleh data lengkap. Instrumen utama pada penelitian ini adalah peneliti itu sendiri. Instrumen bantu yang digunakan dalam penelitian ini adalah soal tes berpikir tingkat tinggi, pedoman wawancara, dan alat rekam. Soal tes berupa 3 soal PISA pada konten change and relationship yang memenuhi indikator berpikir tingkat tinggi dimana masing-masing nomor merepresentasikan masing-masing level berpikir $\mathrm{C} 4, \mathrm{C} 5$, dan C6. Indikator berpikir tingkat tinggi yang digunakan dalam penelitian ini diadaptasi dari Anderson dan Krathwohl yang dapat dilihat pada Tabel 2 berikut.

Tabel 2. Indikator Berpikir Tingkat Tinggi

\begin{tabular}{|c|c|c|}
\hline HOT & $\begin{array}{c}\text { Sumber } \\
\text { Asli }\end{array}$ & Indikator \\
\hline & & $\begin{array}{l}\text { Siswa dapat } \\
\text { menspesifikasi/menguraikan } \\
\text { aspek-aspek/informasi yang } \\
\text { dibutuhkan untuk menentukan } \\
\text { pengehematan biaya konsumsi } \\
\text { bahan bakar kapal kemudian } \\
\text { dapat menentukan lama waktu } \\
\text { yang dibutuhkan untuk } \\
\text { menutup biaya pemakaian } \\
\text { layang-layang dari } \\
\text { penghematan biaya bahan } \\
\text { bakar kapal tersebut }\end{array}$ \\
\hline $\begin{array}{l}\text { Menge } \\
\text { luasi }\end{array}$ & $\begin{array}{l}\text { Mengambil } \\
\text { keputusan } \\
\text { sendiri }\end{array}$ & $\begin{array}{l}\text { Siswa dapat menilai dan } \\
\text { memilih atau mengambil } \\
\text { keputusan sendiri tentang } \\
\text { perusahaan koran yang akan } \\
\text { memberikan keuntungan } \\
\text { terkait jumlah koran yang } \\
\text { dijual dan gaji yang akan } \\
\text { diterima }\end{array}$ \\
\hline $\begin{array}{c}\text { Mencipta } \\
\text { (C6) }\end{array}$ & $\begin{array}{l}\text { Mens } \\
\text { ide/g }\end{array}$ & $\begin{array}{l}\text { Siswa dapat mengkreasi } \\
\text { ide/gagasan sendiri dalam } \\
\text { memformulasikan sebuah } \\
\text { rumus yang tepat dari jumlah } \\
\text { penguin berdasarkan kriteria } \\
\text { pertumbuhan jumlah koloni } \\
\text { penguin yang sudah ditetapkan }\end{array}$ \\
\hline
\end{tabular}

Teknik analisis data dilakukan dengan cara: (1) pengumpulan data, (2) reduksi data, data hasil penelitian tersebut dirangkum dan difokuskan pada hal-hal yang penting sesuai dengan topik penelitian, yaitu kemampuan berpikir tingkat tinggi (3) penyajian data, data disajikan dalam bentuk teks yang bersifat naratif yang disusun dengan baik dan runtut agar mudah dilihat, dibaca, dan dipahami, (4) penarikan kesimpulan. 


\section{Hasil Penelitian dan Pembahasan}

\section{Hasil}

Hasil penelitian berupa deskripsi berpikir tingkat tinggi siswa dalam menyelesaikan soal matematika PISA pada konten change and relationship. Berdasarkan analisis data tes tertulis dan wawancara yang telah dilakukan, dapat diketahui bahwa subjek INA dan subjek PSP dapat mencapai semua level berpikir tingkat tinggi berdasarkan Taksonomi Bloom Revisi. Kedua subjek mampu menjawab dengan tepat 3 soal yang diberikan dimana masing-masing soal merepresentasikan level berpikir mulai dari C4, C5, sampai C6. Kedua subjek juga menunjukkan adanya perbedaan penyelesaian dalam menjawab soal pada level C5 dan C6. Adapun hasil analisis proses berpikir tingkat tinggi subjek INA dan subjek PSP dalam menyelesaikan soal PISA konten change and relationship dapat dilihat pada Tabel 3 berikut.

Tabel 3. Hasil Proses Berpikir Tingkat Tinggi

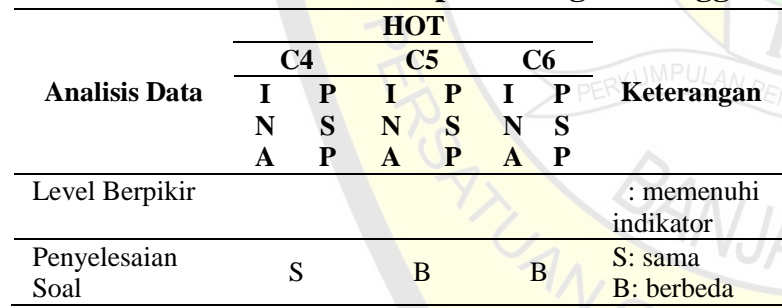

\section{Pembahasan}

\section{$\underline{\text { Soal Menganalisis (C4) }}$}

\section{Karakteristik Soal C4}

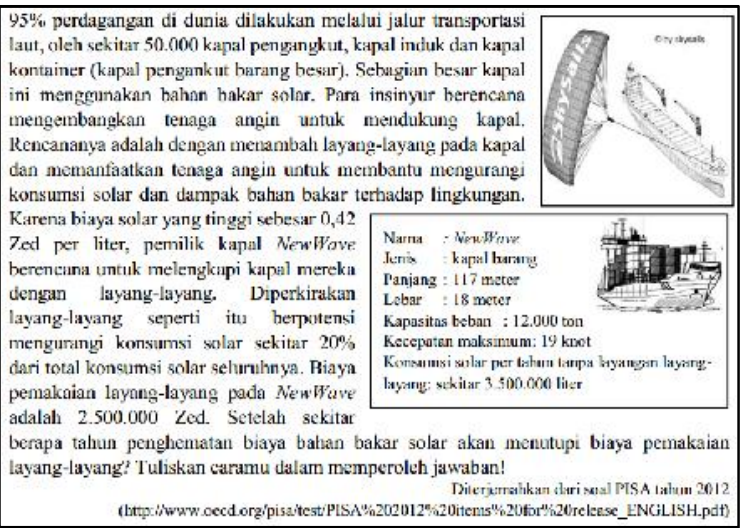

\section{Gambar 1. Soal Tes No. 1 (C4)}

Soal pada Gambar 1 dapat dikategorikan pada level C4 berdasarkan Taksonomi Bloom Revisi karena untuk dapat menjawab permasalahan yang muncul dalam soal yaitu lama waktu yang dibutuhkan untuk menutup biaya pemakaian layang-layang dari penghematan biaya konsumsi solar setelah memakai layang-layang, subjek harus mampu menspesifikasi/menguraikan aspekaspek/informasi yang dibutuhkan untuk menentukan pengehematan biaya konsumsi bahan bakar kapal.

Dalam menguraikan informasiinformasi yang dibutuhkan untuk menjawab soal, tentunya subjek harus paham maksud soal dan mampu melihat informasi-informasi penting yang terdapat dalam soal. Setelah mampu melihat informasi-informasi penting tersebut, maka subjek dapat menguraikan informasi tentang biaya konsumsi solar per tahun tanpa layang-layang, kemudian menentukan biaya konsumsi solar per tahun setelah menggunakan layang-layang yang selanjutnya dapat digunakan untuk menentukan penghematan biaya bahan bakar per tahun sehingga lama waktu yang dibutuhkan untuk menutup biaya pemakaian layang-layang dapat ditentukan. 


\section{Deskripsi Berpikir Tingkat Tinggi Subjek Pada Level Menganalisis (C4)}

\section{Subjek INA}

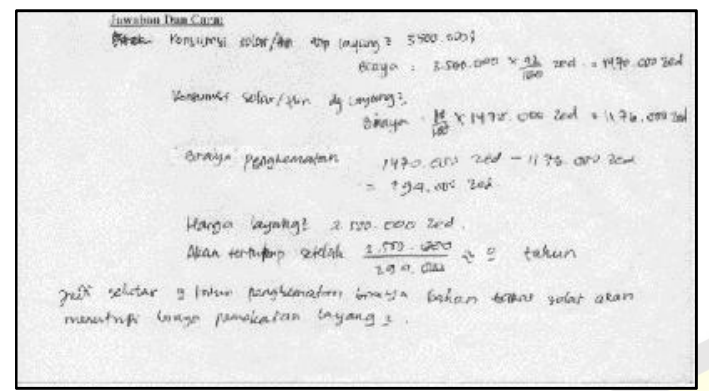

Gambar 2. Hasil Pekerjaan Subjek INA Pada Soal No. 1 (C4)

Hasil analisis tes tertulis dan wawancara subjek INA mengindikasikan bahwa subjek INA mampu menganalisis soal no 1 untuk menyelesaikan permasalahan yang muncul. Subjek mampu memahami maksud dan tujuan soal, kemudian menyaring informasi-informasi penting dalam soal yang meliputi harga solar per liter yaitu 0,42 Zed, pemakaian layang-layang berpotensi mengurangi konsumsi solar sekitar 20\% dari total konsumsi seluruhnya, biaya pemakaian layang-layang 2.500.000 Zed, dan konsumsi solar per tahun tanpa layang-layang adalah 3.500.000 liter. Berdasarkan informasiinformasi yang sudah diperoleh tersebut, subjek menguraikan beberapa informasi yang dibutuhkan sebelum dapat menentukan lamanya waktu untuk menutup biaya pemakaian layang-layang yaitu menentukan informasi biaya konsumsi solar/tahun tanpa layang-layang terlebih dahulu, kemudian menentukan informasi biaya konsumsi solar/tahun dengan layang-layang. Hasil yang diperoleh tersebut selanjutnya digunakan oleh subjek INA untuk menghitung penghematan biaya konsumsi solar/tahun dengan cara mencari selisih antara biaya konsumsi solar sebelum dan sesudah menggunakan layang- layang dan diperoleh hasil sebesar 294.000 Zed.

Dengan diperolehnya besar biaya penghematan maka subjek dapat menentukan lamanya waktu yang diperlukan untuk menutupi biaya pemakaian layang-layang dengan cara membagi besarnya biaya pemakaian layang-layang dengan biaya penghematan. Kemudian subjek INA membuat kesimpulan bahwa biaya pemakaian layang-layang akan tertutup oleh penghematan biaya bahan bakar solar dalam kurun waktu sekitar 9 tahun. Berkaitan dengan kesimpulan yang dibuat oleh subjek, pada saaat wawancara ia juga mampu menjelaskan hasil yang diperolehnya itu sudah menjawab permasalahan yang ada dalam soal. Subjek menjelaskan bahwa sebenarnya ketika besar biaya pemakaian layang-layang dibagi dengan biaya penghematan maka hasil yang diperoleh adalah 8 koma sekian sehingga menurut subjek INA dengan waktu 9 tahun tersebut biaya penghematan bahan bakar sudah pasti dapat menutup biaya pemakaian layang-layang. Berdasarkan hasil analisis jawaban tertulis dan wawancara subjek INA pada soal no 1, maka dapat disimpulkan bahwa subjek INA mampu mencapai dimensi proses berpikir tingkat tinggi pada level C4 berdasarkan Taksonomi Bloom Revisi.

\section{Subjek PSP}

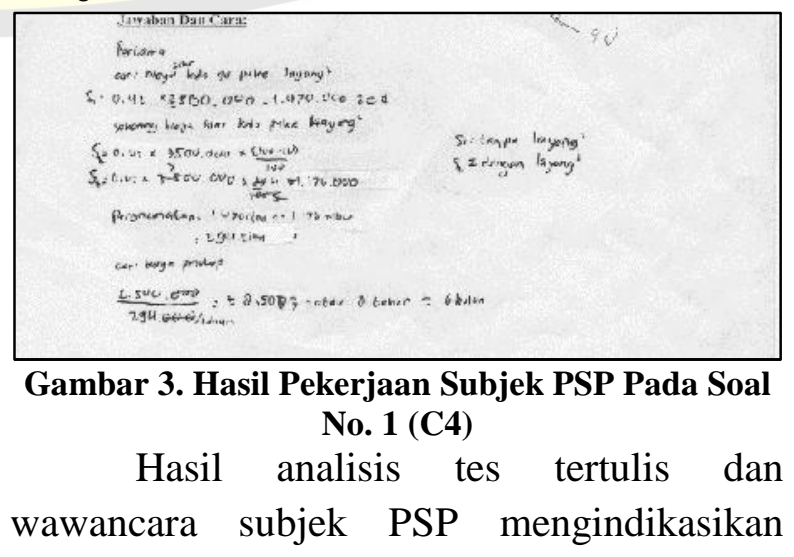


bahwa subjek PSP mampu menganalisis soal no 1 untuk menyelesaikan permasalahan yang muncul. Subjek mampu memahami maksud dan tujuan soal, bahkan ketika diwawancara ia mampu menjelaskan maksud dari apa yang ditanyakan pada soal dengan bahasa subjek senidiri. Subjek PSP mengilustrasikan jika ada kapal dari sebuah perusahaan yang akan memasang layang-layang dengan biaya yang sangat mahal, namun tekhnologi layanglayang itu mampu menghemat konsumsi solar sebesar 20\%. Oleh karena itu, sampai berapa tahun biaya penghematan solar (subjek menganggapnya sebagai keuntungan) tesebut dapat mengembalikan biaya pemakaian layang-layang yang mahal.

Subjek pun juga dapat menyaring informasi-informasi penting dalam soal yang meliputi harga solar per liter yaitu 0,42 Zed, pemakaian layang-layang berpotensi mengurangi konsumsi solar sekitar 20\% dari total konsumsi seluruhnya, biaya pemakaian layang-layang 2.500.000 Zed, dan konsumsi solar per tahun tanpa layang-layang adalah 3.500.000 liter. Berdasarkan informasiinformasi yang sudah diperoleh tersebut, subjek menguraikan beberapa informasi yang dibutuhkan sebelum dapat menentukan lamanya waktu untuk menutup biaya pemakaian layang-layang yaitu menentukan informasi biaya konsumsi solar/tahun tanpa layang-layang terlebih dahulu, kemudian menentukan informasi biaya konsumsi solar/tahun dengan layang-layang. Hasil yang diperoleh tersebut selanjutnya digunakan oleh subjek PSP untuk menghitung penghematan biaya konsumsi solar/tahun dengan cara mencari selisih antara biaya konsumsi solar sebelum dan sesudah menggunakan layanglayang dan diperoleh hasil sebesar 294.000 Zed.
Dengan diperolehnya besar biaya penghematan maka subjek dapat menentukan lamanya waktu yang diperlukan untuk menutupi biaya pemakaian layang-layang dengan cara membagi besarnya biaya pemakaian layang-layang dengan biaya penghematan. Kemudian subjek PSP membuat kesimpulan bahwa biaya pemakaian layanglayang akan tertutup oleh penghematan biaya bahan bakar solar dalam kurun waktu kurang lebih 8,5 tahun. Berdasarkan hasil analisis jawaban tertulis dan wawancara subjek PSP pada soal no 1, maka dapat disimpulkan bahwa subjek PSP mampu mencapai dimensi proses berpikir tingkat tinggi pada level C4 berdasarkan Taksonomi Bloom Revisi.

\section{$\underline{\text { Soal Mengevaluasi (C5) }}$}

\section{Karakteristik Soal C5}

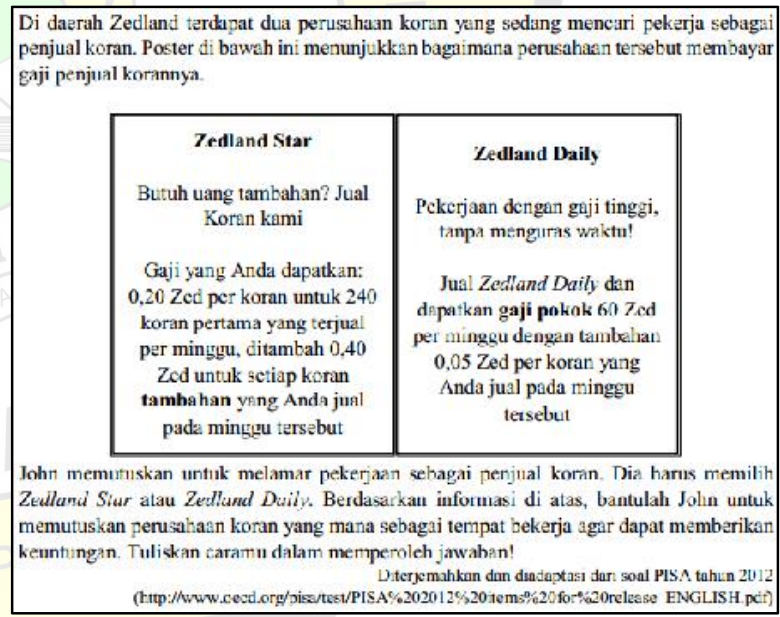

Gambar 4. Soal Tes No. 2 (C5)

Soal pada Gambar 4 dapat dikategorikan pada level C5 berdasarkan Taksonomi Bloom Revisi karena untuk dapat menjawab permasalahan yang muncul dalam soal yaitu menentukan atau memutuskan perusahaan koran yang lebih menguntungkan, subjek harus mampu mengevaluasi kondisikondisi yang muncul dalam permasalahan yaitu pendapatan per minggu jika bekerja di 
perusahaan Zedland Star, pendapatan per minggu jika bekerja di Zedland Daily. Kemudian subjek menilai solusi yang dibuat berdasarkan informasi-informasi gaji tersebut sehingga dapat membantu untuk menentukan atau memutuskan perusahaan koran yang lebih menguntungkan.

Dalam memutuskan perusahaan koran yang akan disarankan kepada John, tentunya subjek harus paham maksud soal dan mampu melihat informasi-informasi penting yang terdapat dalam soal. Setelah mampu melihat informasi-informasi penting tersebut, maka subjek dapat menguraikan informasi tentang gaji yang diperolah pada masing-masing perusahaan, kemudian membandingkan gaji yang diterima dari kedua perusahaan dan menghubungkannya dengan faktor-faktor lain yang dapat mempengaruhi kuantitas penerimaan gaji sehingga dapat memutuskan perusahaan koran yang lebih menguntungkan.

\section{Deskripsi Berpikir Tingkat Tinggi Subjek Pada Level Mengevaluasi (C5)}

\section{Subjek INA}

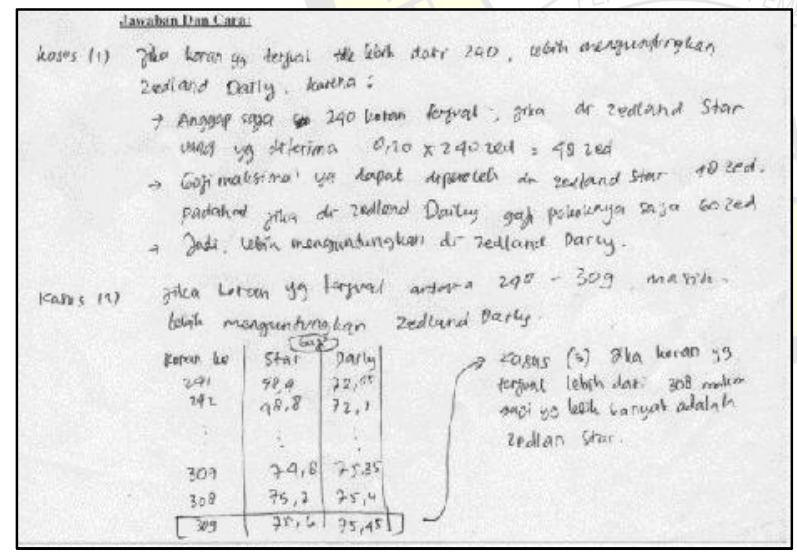

Gambar 5. Hasil Pekerjaan Subjek INA Pada Soal No. 2 (C5)

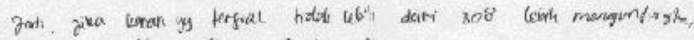

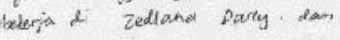

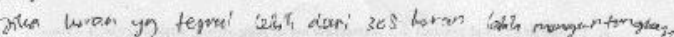

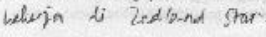

Gambar 6. Kesimpulan Subjek INA Pada Soal No. 2 (C5)
Hasil analisis tes tertulis dan wawancara subjek INA pada soal no 2 menunjukkan bahwa subjek INA mampu memahami maksud dan tujuan soal serta mampu mengevaluasi kondisi-kondisi yang muncul dalam permasalahan yang berkaitan dengan gaji dan jumlah koran yang dijual dimana informasi tersebut nantinya dapat digunakan untuk memilih perusahaan koran yang lebih menguntungkan. Sebelum memilih atau memutuskan perusahaan koran, subjek INA menentukan besarnya gaji yang diperoleh oleh masing-masing perusahaan yaitu antara Zedland Star dan Zedland Daily. Berdasarkan hasil wawancara, subjek INA merasa bahwa informasi yang tersedia masih belum lengkap yaitu tidak adanya informasi rata-rata penjualan koran per tahun sehingga untuk bisa membandingkan gaji yang diterima oleh dua perusahaan tersebut ia membuat tiga kasus.

Kasus pertama jika koran yang dijual kurang dari 240 eksemplar maka lebih menguntungkan bekerja di Zedland Daily, kasus kedua jika koran yang terjual antara 204 sampai 308 eksemplar maka masih menguntungkan bekerja di Zedland Daily namun pada kasus ketiga, ketika koran yang terjual lebih dari 308 buah maka bekerja di Zedland Star akan lebih menguntungkan. Mengacu pada tiga kasus tersebut, akhirnya subjek membuat kesimpulan bahwa jika John hanya mampu menjual koran kurang dari 308 eksemplar maka disarankan untuk bekerja di Zedland Daily tetapi jika John mampu menjual koran lebih dari 308 eksemplar maka disarankan untuk bekerja di Zedland Star. Melihat kesimpulan akhir yang dibuat subjek tersebut dapat dikatakan bahwa subjek INA baru menilai suatu kondisi saja belum sampai memilih dan memutuskan perusahaan koran yang sebaiknya dipilih John. 
Namun pada saat proses wawancara, subjek INA mampu memutuskan perusahaan koran yang lebih menguntungkan dengan mempertimbangkan gaji yang diperoleh dari masing-masing perusahaan koran dan dikaitkan dengan faktor lain yang mempengaruhi kuantitas gaji yang akan diterima seperti yang bisa dilihat dalam petikan wawancara di atas. Awalnya, subjek INA menyarankan John untuk bekerja di Zedland Star karena gaji yang diperoleh di Zedland Daily memang lebih besar tapi hanya terbatas sampai 308 koran yang dijual dan jika koran yang dijual lebih dari 308 buah maka gaji yang didperoleh dari Zedland Star lebih banyak.

Akan tetapi, selang beberapa saat subjek INA meralat jawabanya, ia lebih menyarankan John untuk bekerja di Zedland Daily saja dengan alasan kalau di Zedland Star agar bisa memperoleh gaji lebih banyak maka harus menjual lebih dari 308 namun jika melihat kondisi sekarang dimana koran sudah mulai kalah dengan berita online yang mudah diakses dengan gadget maka untuk menjual 308 koran akan susah dan belum tentu bisa menjual sebanyak itu, sehingga lebih menguntungkan bagi John untuk bekerja di Zedland Daily. Berdasarkan hasil analisis jawaban tertulis dan wawancara subjek INA pada soal no 2, maka dapat disimpulkan bahwa subjek INA mampu mencapai dimensi proses berpikir tingkat tinggi pada level C5 berdasarkan Taksonomi Bloom Revisi.

\section{Subjek PSP}

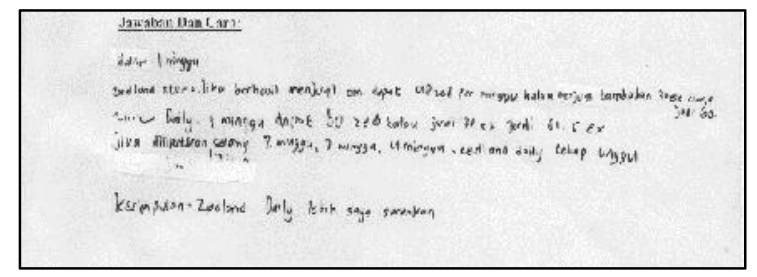

Gambar 7. Hasil Pekerjaan Subjek PSP Pada Soal No. 2 (C5)
Hasil analisis tes tertulis dan wawancara subjek PSP pada no 2 mengindikasikan bahwa subjek PSP mampu memahami maksud dan tujuan soal serta mampu mengevaluasi kondisi-kondisi yang muncul dalam permasalahan yang berkaitan dengan gaji dan jumlah koran yang dijual dimana informasi tersebut nantinya dapat digunakan untuk memilih perusahaan koran yang lebih menguntungkan. Sebelum memilih atau memutuskan perusahaan koran, subjek PSP menentukan besarnya gaji yang diperoleh oleh masing-masing perusahaan yaitu antara Zedland Star dan Zedland Daily. Berdasarkan jawaban tertulis, subjek PSP hanya membandingkan perolehan gaji kedua perusahaan tersebut ketika koran yang terjual sebanyak 270 koran saja kemudian langsung memutuskan Zedland Daily yang lebih disarankan kepada John sebagai tempat bekerja.

Namun pada saat proses wawancara, subjek PSP juga menjelaskan kondisi dimana Zedland Star akan memberikan gaji yang lebih banyak dari pada Zedland Daily. Subjek mencoba membandingkan perolehan gaji ketika koran yang berhasil dijual sebanyak 330 eksemplar dengan diperoleh hasil bahwa gaji yang diterima dari Zedland star akan lebih besar apalagi jika mampu menjual koran lebih banyak lagi maka semakin besar pula gaji yang diterima. Akan tetapi pada akhirnya subjek PSP tetap menyarankan John untuk bekerja di Zedland Daily dengan mempertimbangkan gaji yang diperoleh dari masing-masing perusahaan koran dan dikaitkan dengan faktor lain yang mempengaruhi kuantitas gaji yang akan diterima.

Awalnya subjek PSP membuat kesimpulan jika dalam satu minggu John mampu menjual koran sekitar 400 eksemplar atau lebih maka lebih disarankan untuk bekerja 
di Zedland Star karena gajinya pasti akan lebih besar, namun kemudian subjek PSP juga mempertimbangkan kondisi zaman sekarang dimana untuk menjual koran sebanyak itu pasti akan susah karena koran atau media cetak sudah mulai tergeser dengan media elektronik seperti detik.com yang mudah diakse melalui HP atau gadget sehingga subjek menyarankan kepada John untuk bekerja di Zedland Daily saja. Berdasarkan hasil analisis jawaban tertulis dan wawancara subjek PSP pada soal no 2, maka dapat disimpulkan bahwa subjek PSP mampu mencapai dimensi proses berpikir tingkat tinggi pada level C5 berdasarkan Taksonomi Bloom Revisi.

\section{$\underline{\text { Soal Mencipta/Mengkreasi (C6) }}$}

\section{Karakteristik Soal C6}

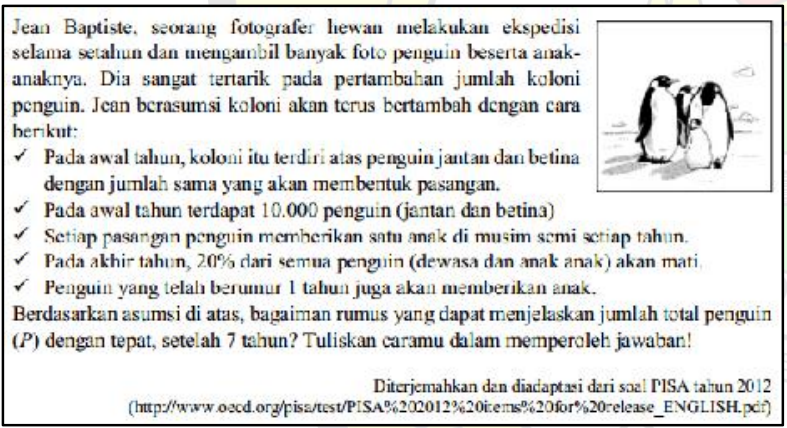

Gambar 8. Soal Tes No. 3 (C6)

Soal pada Gambar 8 dapat dikategorikan pada level C6 berdasarkan Taksonomi Bloom Revisi karena untuk dapat menjawab permasalahan yang muncul dalam soal yaitu memformulasikan sebuah rumus yang dapat menggambarkan jumlah total penguin $(P)$ dengan tepat setelah 7 tahun berdasarkan kriteria pertumbuhan penguin yang sudah ditetapkan. Sebelum memformulasikan rumus tersebut, subjek harus menguraikan dan menilai informasiinformasi yang sudah tersedia dalam soal yang kemudian dapat digunakan sebagai petunjuk dalam menyusun atau mengkreasikan sebuah rumus. Untuk memformulasikan rumus jumlah tersebut tentunya subjek harus paham maksud soal dan mampu melihat informasi-informasi penting yang terdapat dalam soal.

\section{Deskripsi Berpikir Tingkat Tinggi Subjek Pada Level Mencipta/Mengkreasi (C6)}

\section{Subjek INA}

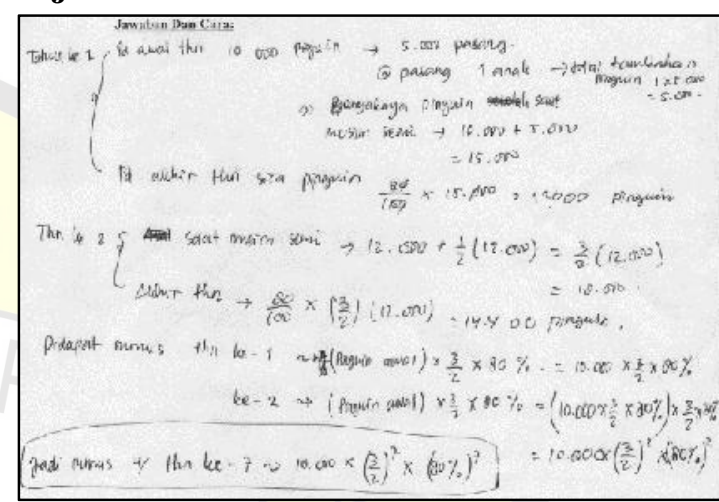

Gambar 9. Hasil Pekerjaan Subjek INA Pada Soal No. 3 (C6)

Hasil analisis tes tertulis dan wawancara subjek INA pada soal no 3 mengindikasikan bahwa subjek INA mampu memahami maksud dan tujuan soal serta mampu menguraikan hal-hal penting yang diperlukan untuk membuat rumus tentang jumlah total penguin seperti kuantitas awal penguin dimana jumlah penguin jantan dan betina sama yang akan membentuk pasangan, setiap pasangan penguin akan menghasilkan 1 anak, pada akhir tahun $20 \%$ penguin akan mati yang berarti sisa $80 \%$ penguin yang hidup, dan penguin yang telah berumur 1 tahun juga mampu memberikan anak. Informasiinformasi tersebut kemudian diterjemahkan secara matematis dan diaplikasikan dalam perthitungan subjek.

Dalam memformulasikan rumus jumlah total penguin, subjek INA mula-mula menghitung jumlah total penguin tahun pertama dengan menggunakan informasiinformasi yang sudah diketahui dari soal yaitu dengan cara banyak penguin mula-mula yang 
berjumlah 10.000 ekor (jantan dan betina) ditambah anak penguin yang dihasilkan. Dikarenakan penguin jantan dan betina diketahui jumlahnya sama dan akan membentuk pasangan dengan menghasilkan 1 anak sehingga anak yang dihasilkan adalah setengah dari jumlah awal penguin yaitu 5.000 ekor maka jumlah penguin menjadi 15.000 ekor. Pada akhir tahun, penguin yang masih hidup sebanyak $80 \%$ sehingga jumlah penguin di tahun pertama menjadi

$80 \% \times 15.000=12.000$

Subjek melihat pola perhitungan yang tersirat pada jawaban tersebut sehingga membuat rumus jumlah penguin untuk tahun pertama adalah

$p \quad a \quad \times \frac{3}{2} \times 80 \% \quad$ (2)

sehingga total penguin menjadi

$10.000 \times \frac{3}{2} \times 80 \%$

Pada tahun kedua, langkah perhitungan subjek INA sama seperti (2) namun yang membedakan adalah jumlah awal penguin. Berdasarkan wawancara, subjek menjelaskan bahawa jumlah akhir penguin ditahun pertama akan menjadi jumlah awal penguin di tahun kedua dan berlaku untuk tahun-tahun selanjutnya. Karena cara yang digunakan sama dengan tahun pertama maka rumus jumlah penguin tahun kedua akan sama seperti (2) akan tetapi penguin awal pada tahun kedua tersebut disubstitusi oleh jumlah akhir penguin tahun pertama yang sudah diketahui yaitu (3). Sehingga jumlah total penguin pada akhir tahun kedua menjadi

$$
\begin{aligned}
& 10.000 \times \frac{3}{2} \times 80 \% \times \frac{3}{2} \times 80 \%=10.000 \times \\
& \left(\frac{3}{2}\right)^{2} \times(80 \%)^{2}
\end{aligned}
$$

Dengan melihat pola yang terbentuk antara rumus jumlah total penguin (2), (3), dan (4) maka subjek menyimpulkan bahwa untuk rumus jumlah total penguin setelah 7 tahun menjadi

$$
10.000 \times\left(\frac{3}{2}\right)^{7} \times(80 \%)^{7}
$$

Pada saat proses wawancara, subjek juga menjelaskan bahwa karena yang selalu berubah adalah pangkat yang menggambarkan tahun yang ditanyakan maka subjek juga mengkreasi rumus total penguin untuk $n$ tahun menjadi

$10.000 \times\left(\frac{3}{2}\right)^{n} \times(80 \%)^{n}$

dimana $n$ melambangkan tahun yang ditanyakan. Berdasarkan hasil analisis jawaban tertulis dan wawancara subjek INA pada soal no 3, maka dapat disimpulkan bahwa subjek INA mampu mencapai dimensi proses berpikir tingkat tinggi pada level C6 berdasarkan Taksonomi Bloom Revisi.

\section{Subjek PSP}

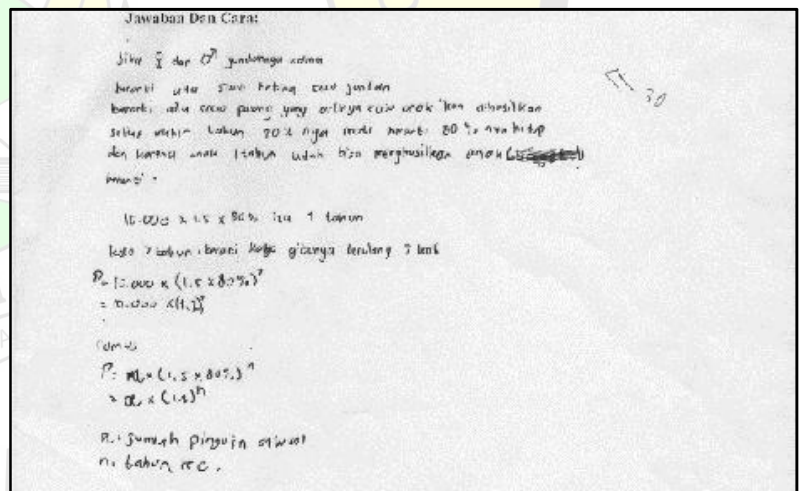

Gambar 10. Hasil Pekerjaan Subjek PSP Pada Soal No. 3 (C6)

Hasil tes tertulis dan 1 wawancara subjek PSP pada soal no 3 mengindikasikan bahwa subjek PSP mampu memahami maksud dan tujuan soal serta mampu menguraikan halhal penting yang diperlukan untuk membuat rumus tentang jumlah total penguin seperti kuantitas awal penguin dimana jumlah penguin jantan dan betina sama yang akan membentuk pasangan, setiap pasangan penguin akan menghasilkan 1 anak, pada akhir tahun $20 \%$ penguin akan mati yang berarti sisa $80 \%$ penguin yang hidup, dan penguin yang 
telah berumur 1 tahun juga mampu memberikan anak. Informasi-informasi tersebut kemudian diterjemahkan secara matematis dan diaplikasikan dalam perthitungan subjek.

Dalam memformulasikan rumus jumlah total penguin, subjek PSP mula-mula menghitung jumlah total penguin tahun pertama dengan menggunakan informasiinformasi yang sudah diketahui dari soal yaitu dengan cara banyak penguin mula-mula yang berjumlah 10.000 ekor (jantan dan betina) ditambah anak penguin yang dihasilkan. Dikarenakan penguin jantan dan betina diketahui jumlahnya sama dan akan membentuk pasangan dengan menghasilkan 1 anak sehingga anak yang dihasilkan adalah setengah dari jumlah awal penguin yaitu 5.000 ekor maka jumlah penguin menjadi 15.000 ekor dengan kata lain jumlah penguin menjadi 1,5 lebih banyak. Pada akhir tahun, penguin yang masih hidup sebanyak $80 \%$ sehingga jumlah penguin di tahun pertama menjadi $80 \% \times 15.000=12.000$

Subjek melihat pola perhitungan yang tersirat pada jawaban tersebut dimana jika kematian tidak diperhitungkan maka setiap tahun jumlah penguin menjadi 1,5 kali dari jumlah awal, namun karena pada akhir tahun sebanyak $20 \%$ penguin mati maka sisa $80 \%$ penguin yang hidup sehingga untuk setiap tahun penguin yang tersisa adalah

\section{$1,5 \times 80 \%=1,2$}

Atau dengan kata lain 1,2 dari jumlah awal penguin. Sehingga jumlah penguin sebanyak 12.000 ekor ditahun pertama seperti yang disebutkan sebelumnya dapat diperoleh dengan cara

$$
p \quad a \quad \times 1,2=10.000 \times 1,2 \quad \text { (9) }
$$

Berdasarkan informasi pertambahan penguin yang sudah diketahui dari soal adalah sama dari tahun ke tahun serta berdasarkan hasil perhtiungan penguin yang hidup di tahun pertama di mana jumlah penguin menjadi 1,2 dari jumlah awal, maka subjek PSP memutuskan bahwa setiap tahun jumlah penguin akan 1,2 kali dari jumlah awal. Artinya, pada tahun pertama jumlah total penguin adalah seperti pada (9) kemudian setelah tahun kedua maka jumlah total penguin menjadi 1,2 dari jumlah penguin sebelumnya atau

$10.000 \times 1,2 \times 1,2 \quad(10)$

begitupun untuk tahun seterusnya akan terus dikalikan dengan 1,2. Sehingga rumus jumlah total penguin setelah 7 tahun adalah jumlah awal penguin dikalikan dengan 1,2 sebanyak 7 kali dan karena subjek PSP menyebutkan itu merupakan perkalian berulang maka rumus tersebut dapat diubah menjadi

$10.000 \times(1,2)^{7}$

Pada tahap akhir penyelesaian subjek juga mengkreasi rumus total penguin untuk $n$ tahun menjadi

$P=a \times(1,5 \times 80 \%)^{n}$

$=10.000 \times(1,2)^{n} \quad(12)$

dimana $a$ menyatakan jumlah penguin awal dan $n$ menyatakan tahun yang ditanyakan. Berdasarkan hasil analisis jawaban tertulis dan wawancara subjek PSP pada soal no 3, maka dapat disimpulkan bahwa subjek PSP mampu mencapai dimensi proses berpikir tingkat tinggi pada level C6 berdasarkan Taksonomi Bloom Revisi.

\section{Simpulan dan Saran}

\section{Simpulan}

Berdasarkan hasil analisis dan pembahasan, secara keseluruhan dapat disimpulkan bahwa subjek INA dan subjek PSP mampu mencapai semua level berpikir tingkat tinggi (HOT) mulai dari menganalisis 
(C4), mengevaluasi (C5), dan Taksonomi Bloom Revisi. Subjek INA dan subjek PSP menunjukkan adanya perbedaan dalam menyelesaikan permasalahan pada soal mengevaluasi (C5) dan mencipta/mengkreasi (C6) sedangkan untuk soal menganalisis (C4) tidak ada perbedaan penyelesaian yang ditunjukkan oleh kedua subjek. mencipta/mengkreasi (C6) berdasarkan

\section{Daftar Pustaka}

Edo, S. I., Hartono, \& Ilma, R. (2012). Investigating Secondary School Students' Difficulties in Modelling Problems PISA-Model level 5 and 6. Journal on Mathematics Education (IndoMS. J.M.E), 4(1), 41-58.

Gunawan, Adi W. (2003). Genius Learning Strategy: Petunjuk Praktis Untuk Menerapkan Accelerated Learning. Jakarta: PT. Gramedia Pustaka Utama.

\section{Saran}

Berdasarkan hasil penelitian yang sudah dilaksanakan, ada beberapa saran yang perlu disampaikan yaitu (1) bagi siswa, diharapkan siswa dapat menambah porsi latihan soal tidak hanya dari satu sumber saja terutama untuk soal yang membutuhkan penalaran lebih tinggi, sehingga dapat melatih dan meningktkan HOTS siswa tersebut, (2) bagi guru, hendaknya guru dapat memfasilitasi soal-soal yang memuat kemampuan menganalisis (C4), mengevaluasi (C5), dan mencipta/mengkreasi (C6) bagi siswa dikarenakan selama ini siswa belum terbiasa dengan soal-soal HOTS dan sudah merasa nyaman dengan soal yang berada pada level MOTS maupun LOTS saja, dan (3) bagi peneliti lain, level instrumen soal PISA yang digunakan dalam penelitian ini masih bersifat acak dan belum menyeluruh, diharapkan adanya penelitian lebih lanjut mengenai berpikir tingkat tinggi siswa dalam menyelesaikan soal matematika PISA menggunakan instrumen soal PISA mulai dari level 1 sampai level 6 serta diharapkan penelitian ini dapat dijadikan referensi untuk penelitian selanjutnya.
Heong, Y. M., dkk. (2011). The Level of Marzano Higher Order Thinking Skills among Technical Education Students. International Journal of Social and humanity, 1(2), 121-125.

Mujaid, Achmad. (2015). Analisis Kemampuan Berpikir Matematika Siswa Berdasarkan Taksonomi Bloom Revisi. Tesis, tidak dipublikasikan. Program Pascasarjana Universitas Terbuka Jakarta.

OECD. (2012). PISA 2012: Data Tables, Figures, and Exhibits. Diakses tanggal $18 \quad$ Februari 2018 dari https://nces.ed.gov/pubs2014/2014024_t ables.pdf.

OECD. (2015). Draft PISA 2015 Mathematics Framework. Diakses tanggal 18 Februari 2018

dari https://www.oecd.org/pisa/pisaproducts/ Draft\%20PISA\%202015\%20Mathemati cs\%20Framework\%20.pdf.

Setiawan, H., dkk. (2014). Soal Matematika Dalam PISA Kaitannya Dengan Literasi Matematika Dan Kemampuan Berpikir Tingkat Tinggi. Prosiding Seminar Matematika Dan Pendidikan Matematik, 1(1). Jember: Univesitas Jember.

Susanti, Elsa \& Syam, Salmaini S. (2017). Peran Guru dalam Meningkatkan Kemampuan Literasi Matematika Siswa Indonesia. Prosiding Seminar Nasional Matematika dan 
Pendidikan Matematika yang diselenggarakan oleh FMIPA UNY, tanggal 11 November 2017. Yogyakarta: Universitas Negeri Yogyakarta.

Syahwaludi, Muhammad. dkk. (2016). Higher Order Thingking Skills Siswa Pada Materi Statistika Kelas XI IPA MAN 2 Pontianak. Jurnal Pendidikan dan Pembelajaran, 5(11).

Wardhani, Sri \& Rumiyati. (2011). Instrumen Penilaian Hasil Belajar Matematika SMP: Belajar dari PISA dan TIMSS. Yogyakarta : Pusat Pengembangan dan Pemberdayaan Pendidik dan Tenaga Kependidikan (PPPPTK) Matematika.

Widana, I Wayan. (2017). Modul Penyusunan Soal High Order Thinking Skill (HOTS). Jakarta: Direktorat Pembinaan SMA Direktorat Jenderal Pendidikan Dasar Dan Menengah Departemen Pendidikan Dan Kebudayaan. 